\title{
Civic Education of the Technical University Students in Foreign Language Classes
}

\author{
Roza A. Valeeva ${ }^{1}$, Natalya E. Koroleva ${ }^{2} \&$ Farida K. Sakhapova ${ }^{2}$ \\ ${ }^{1}$ Kazan (Volga region) federal university, Kazan, Russia \\ ${ }^{2}$ Kazan (Volga Region) Federal University Branch in Naberezhnye Chelny, Naberezhnye Chelny, Russia \\ Correspondence: Roza A. Valeeva, Kazan (Volga region) federal university, Mezhlauka street 1, Kazan, 420021, \\ Russia.
}

Received: October 24, 2014 Accepted: December 3, 2014 Online Published: December 18, 2014

doi:10.5539/res.v7n1p176

URL: http://dx.doi.org/10.5539/res.v7n1p176

\begin{abstract}
The article is devoted to the theory and techniques of the young people civic education. It also deals with the problems of students' civic consciousness and civic qualities formation. The purpose of the research was to study and diagnose civic consciousness of Technical University Students, to ground theoretically and test experimentally pedagogical conditions of students' civic consciousness formation in foreign language classes. The results of the definition and specification of the notion of "civic education" are also introduced in the article. Forms and methods of efficient work in classroom and extra-curricular work with students while studying a foreign language are revealed and experimentally checked. The efficiency of testing, dialogue around, role-playing games, press conferences, debates in civic consciousness formation is approved.
\end{abstract}

Keywords: civic education, civic consciousness, civic qualities, criteria, skills, levels, content, tasks, forms, methods of civic education, the formation of civic consciousness and civic qualities, foreign language classes

\section{Introduction}

\subsection{Actualization of the Problem}

In the history of education the idea of the civic education evolution is closely connected with changes in the historical characteristics of the society, the development of social problems, the understanding of the ideal person. The origins of the theory of civic education are in the socio-political development of the society. The proximate cause of its threshold is the formation of the state that defined "study of the role of government in the organization of all aspects of social existence. Individualistic philosophy varied and the transition to the active involvement of citizens in public life was made. This idea was reflected in the upbringing of children, aimed on the formation of the common aspirations and goals so that the country's population became one happy family with the slogan "... one for all and all for one ..." and the political activity was replaced for the social, by means of the involvement of children and the population in a volunteer movement, charity, church communities and the creation of other forms of active participation not in the political but in the social life of the society. (Fakhrutdinova, 2010a, p. 163).

In the current political and socio-economic conditions of Russia the significance of civic education becomes more and more relevant. Economic disintegration, differentiation of society, devaluation of spiritual values had a negative impact on public consciousness of most social and age groups of the population, particularly on youth. This is evident in the increasing apathy, selfishness, cynicism, drug addiction, unmotivated aggression, disrespectful attitude towards the state and social institutions. Anxiety symptoms of these phenomena are multidimensional and in the conditions of destabilization of the Russian economy carry dangerous potential of moral degradation of young people (Fakhrutdinova, 2010b). That is why the need for education of the person capable of implementing the state's interests has been actual.

\subsection{Explore Importance of the Problem}

The idea of citizenship for the development of society is reflected in the traditional opposition categories: private and public interest. The ratio of people-society at various times has taken different forms and dictated his vision of a man as a citizen (Fakhrutdinova, 2010b). 
To solve the problem of civic education successfully it is necessary to pay special attention to civic education of students, future professionals. The revival of Russia today and its tomorrow life will increasingly depend on the moral and civic qualities of our youth. Civic education at this stage is a versatile, multi-purpose, multidirectional activity, aimed on the formation of a personality able to benefit society that considers itself legally, socially and politically viable. Successful implementation of students' civic education may be achieved through a number of conditions on the state level: the development of standards, financial and ideological support. Educational standards and / or frameworks for civic and related subjects can be implemented as an interdisciplinary level and represent the disciplines adopted at a particular stage of learning (Fakhrutdinova, 2011, p. 69).

\subsection{The students' Psychological Characteristics}

Purposeful activity on the formation of students' citizenship is impossible without taking into account the psychological characteristics of this group of young people. According to sociologists and psychologists, in particular E. P. Veremeeva, being a student is a time of the most intensive development of intellectual and moral capacities of a person, the foundation of personality (Veremeeva, 1980). At this time, more serious attitude to life, greater autonomy is gradually coming. The responsibility for the actions, the aspiration to establish stable relations with people in a meaningful dialogue, the active and creative solution of professional problems, sensibility of thoughts and maturity judgments appeared. This period in a person's life is characterized by the rapid development of moral sense (Veremeeva, 1980, p. 38). Analyzing the psychological traits of the students, Jay (2011) emphasizes the qualities that make up a very fruitful base for the educational work at the university. This is a searching and inquisitive curiosity, increased sensitivity and action, responsibility and commitment to Romanticism, directness and honesty, and high demands on themselves and others. Among the students criticism and self-criticism a strict attitude to friends and teachers are strongly developed. A desire to comprehend and critically argue everything that still does not raise any doubts, especially should be taken into account when implementing the students' civic education.

\subsection{Theoretical Background}

Theoretical foundations of civic education of the younger generation have been covered in the scientific works of psychologists, educators, lawyers, philosophers and sociologists of different eras. So, the basics of civics are discovered in the works of Rogova, Rabinovich and Sakharov (1991), Gajazov (1995), Hollander (2011).

Philosophical and social aspects of civic education are disclosed in the papers of Hutchinson (2011). General theoretical foundations are developed by Stanton (2007). Problems of students' civic consciousness and civic qualities formation are studied by Lesher (1997). The international experience of civic education was studied by Fakhrutdinova (2010a). The educational potential of a foreign language was disclosed by Yuzlikaeva (1991). Although all those studies have obtained certain data revealing objectives, the content and methods of civic education, and they have not lost their value in some cases, it's necessary to reconsider these basics because they do not meet the new conditions.

Thus, by nowadays there is a contradiction, on the one hand, between the needs of modern society in a socially active personality of the future professionals with strong civil qualities, and on the other hand there is a lack of theoretical and practical basics of modern students' civic education. This calls for identifying and studying the forms and methods of the technical university students' citizenship development in a foreign language classroom in high school.

\section{Materials and Methods}

\subsection{The Aim and Tasks of the Research}

The aim of the present study is the theoretical analysis and experimental testing of the forms and methods of the Technical University Students' civic consciousness development by means of foreign language.

The tasks of the research are: 1) to choose the experimental and control groups of students; 2) to diagnose the level of students' civic consciousness comparing its cognitive, emotional and personal and practice-effective components; 3 ) to organize forming experiment during the foreign language classes; 4) to analyze the results of the experimental teaching, to assess its effectiveness.

\subsection{Theoretical and Empirical Methods}

In compliance with the goal, the following methods have been selected:

- theoretical - analysis of the pedagogical and psychological literature; study and generalization of innovative pedagogical experience, analysis, synthesis;

- empirical—participant observation, ascertaining and forming pedagogical experiment, questionnaires, tests, 
interviews, conversations, learning outcomes of educational and extracurricular activities of students, as well as methods of mathematical statistics

\subsection{Evaluation Criteria}

We used three indicators while examining the Technical University Students' civic consciousness level:

1) Cognitive (purposeful perception and comprehension of the phenomena studied, associated with the knowledge of another person, including the ability to effectively deal with problems that arise between people);

2) The emotional and personal (including emotional responsibility, sensitivity to another person, empathy and compassion, attention to the actions of partners);

3) Practice-effective (creative reworking during the execution of speech acts, the active application in practice reflects the ability of students to cooperate, joint activities, the adequacy of communication, organizational and communication skills, etc.).

To assess the cognitive measurement, we used the method of contextual learning. From the point of view of Bloomfield (2005) the criterion of a teacher and students in the contextual learning is a situation. Communication in such situations is a means of cognitive activity; it involves the formation and development of the ability to learn, that is formation as special skills and general education skills, as well as to regulate the conduct of personality and to induce to certain speech and non-speech action for interaction. It promotes the formation of value orientations, attitudes and beliefs of the person, serves as a means of speech processing behavior of people and their relationships.

To assess the emotional and personal indicator we used training discussions. During the discussion, students learn to discuss vital issues, to convince arguments, to defend their point of view and refute the opinion of the opponent, and to draw conclusions, clarify facts and summarize incoming information. The development of civil beliefs is carried out through familiarization with the cultural values of the country of the studied language, with advances in various fields of science and technology of the country, through the emotional and personal assessment of the educational material.

To assess the practical-action component successfully role playing and business games are used helping students to communicate in the target language. Participation in these games allows developing civil beliefs, a sense of tact towards the partner in communication, polite and friendly ability to bring it to the desired results of negotiation or conflict resolution. Through business and role-playing games memory, attention, thinking, learning is improved, i.e. purposeful perception and comprehension of the phenomena occurs while being studied, their creative reworking during the execution of speech acts accomplishes from the conscious mastery of action to automated implementation (Fakhrutdinova, 2012, p. 135).

The level of development of civic consciousness was defined as an integrative indicator by all methods and is defined as follows: the low level: from 1 to 6 points; the middle level: from 7 to 12 points; the high level: from 13 to 15 points.

The study involved more than 502 students of the first, second, third, fourth year of study. To prove the hypotheses of the study we used the methods of mathematical statistics, t-Student test.

\section{Results}

Using programs to build students' citizenship should be based on the age characteristics, related to the students' experience in variety of forms: educational, recreational, organization of functioning of the educational environment of the institution. Methods of obtaining knowledge and the development of intellectual skills in the formation of active citizenship are classified as methods of thinking - critical, analytical, reflective and strategic (Gajazov, 1995, p. 157).

Taking into account the students' specific nature, we determined the specificity of students' civic education by means of a foreign language, which includes the differentiated approach, interest to a foreign language in specific form of studies (discussion on problem questions, press conferences, a teleconference, dialogue around).

We defined three levels of students' civic consciousness formation: high, average, low allowing to define the field of influence on the civic consciousness by means of foreign language learning activities.

High level is characterized by steady and positive experience of the civil behavior, the responsible relation to observance of laws, labor and public duties.

For the average level the steady positive behavior, regulation and self-control existence is shown though the active civic stand is not always peculiar. 
Low level of formation of civic consciousness of students is characterized by weak manifestation of the positive, unstable experience of civil behavior.

Among the diagnosed qualities we number: public consciousness of the personality, performance of a civic duty, understanding of the rights and duties, civic position.

These levels and criteria were used by us during stating and forming stages of pedagogical experiment by comparison of levels of students of experimental and control groups before and after the experiment.

The results of diagnostics students' civic consciousness development at a stating stage of the experiment are presented in table 1 .

Table 1. Students' civic consciousness development at the stating stage of the experiment

\begin{tabular}{lll}
\hline Level & $\begin{array}{l}\text { The Experiment Group level (total } \\
\text { of students-124 people) }\end{array}$ & $\begin{array}{l}\text { Control Group level (total of } \\
\text { students-128 people) }\end{array}$ \\
\hline High & $23.7 \%$ & $26.2 \%$ \\
Average & $36.1 \%$ & $38.7 \%$ \\
Low & $40.2 \%$ & $35.1 \%$ \\
\hline
\end{tabular}

Summing up the results of a stating stage of experiment, we noted that there is no uniform and complete, effective system of students' civic consciousness formation by means of a foreign language. The main indicator of civic consciousness development is transition from the low level to the average, and from the average to the high level. At forming experiment teaching and educational process in control group was carried out according to the traditional program with the use of classical means and methods of education.

After carrying out work on civil education in experimental group it became clear that level of formation of civic consciousness of students became much higher: the conscious system of civil requirements of students to each other was created, knowledge of the civil rights, duties, guarantees was systematized and consolidated. All this allows drawing a conclusion that forms and the methods used by us in classroom educational work, shows positive results.

Changes of students' civic consciousness level at the control stage of experiment are reflected in table 2.

Table 2. Changes of students' civic consciousness level at the control stage of experiment

\begin{tabular}{lll}
\hline Level & $\begin{array}{l}\text { The Experiment Group level (total } \\
\text { of students - 126 people) }\end{array}$ & $\begin{array}{l}\text { Control Group level (total of } \\
\text { students - 124 people) }\end{array}$ \\
\hline High & $33.1 \%$ & $26.2 \%$ \\
Average & $38.8 \%$ & $41.5 \%$ \\
Low & $28.1 \%$ & $32.3 \%$ \\
\hline
\end{tabular}

The comparative analysis of the students' civic consciousness level changes is reflected in table 3.

Table 3. Dynamics of level of formation of civic consciousness at students of EG and CG

\begin{tabular}{l|lc|lc}
\hline Level & $\begin{array}{l}\text { The Level of Formation of Civic } \\
\text { Consciousness } \\
\text { entrance" }\end{array}$ & $\begin{array}{l}\text { Level of formation of civic } \\
\text { consciousness "at the exit" }\end{array}$ \\
\hline High & EG & CG & EG & CG \\
Average & $23.7 \%$ & $26.2 \%$ & $33.1 \%$ & $26.2 \%$ \\
Low & $36.1 \%$ & $38.7 \%$ & $38.8 \%$ & $41.5 \%$ \\
\hline
\end{tabular}

The obtained data testify that during work there was an essential shift of accents in understanding by the students 
of essence of civic consciousness. Reliability of statistical data it was checked by t-Student test.

EG

\begin{tabular}{|c|c|}
\hline All in all-126 people. & 14 people.- "5" \\
\hline High points & 28 people._- "4" \\
\hline \multicolumn{2}{|l|}{$(4,5)-33.1 \% \approx 42$ people. } \\
\hline Average points & 49 people._-“3”' \\
\hline \multicolumn{2}{|l|}{$-38.8 \% \approx 49$ people. } \\
\hline Low points & 35 people._- "2” \\
\hline$-28.1 \% \approx 35$ people. & \\
\hline
\end{tabular}

$\bar{x}_{\ni \Gamma}=\frac{14 \cdot 5+28 \cdot 4+49 \cdot 3+35 \cdot 2}{126} \approx 3,17$

$\bar{x}_{\ni \Gamma} \approx 3,17$

$\overline{x_{\ni \Gamma}^{2}}=\frac{14 \cdot 5^{2}+28 \cdot 4^{2}+49 \cdot 3^{2}+35 \cdot 2^{2}}{126}=10,94$

$Д_{Э \Gamma}=\overline{x_{Э \Gamma}^{2}}-\bar{x}_{\ni \Gamma}^{2}=10,94-3,17^{2} \approx 0,89$

$Д_{э \Gamma} \approx 0,89$

$\sigma_{Э Г}=\sqrt{Д_{Э Г}}=\sqrt{0,89}=0,94$

CG

\begin{tabular}{lc}
\hline All in all-124 people & 10 people.-“5” \\
High points & 22 people.-“4” \\
$(4,5)-26.2 \% \approx 32$ people. & \\
Average points & 52 people.-“" $3 "$ \\
$-41.5 \% \approx 52$ people. & \\
Low points & 40 people.-C" $2 "$ \\
$-32.2 \% \approx 40$ people. & \\
\hline
\end{tabular}

\section{Conclusion}

The essence of civil education includes today the civic consciousness formation as integrative quality of the personality. We defined the civil education as a process of the pedagogical conditions creation providing development of the personality, capable to realize created in the society norm and ideals according to public values, own interests and a civic position. Forms and methods of the educational work efficiency increasing in classroom and extra-curricular work while studying a foreign language at a higher education institution are revealed and experimentally checked. During the experimental work forms of civic consciousness formation - testing, dialogue around, role-playing games, press conferences, debates are approved.

\section{References}

Bloomfield, V. (2005). Civic engagement and graduate education. Communicator, 38(3), 1-2.

Fakhrutdinova, A. V. (2010a). Active citizenship student in a single educational space: International experience. 
Kazan Pedagogical Journal, 1, 163-170.

Fakhrutdinova, A. V. (2010b). The role of the students' civic education in terms of international integration (pp. 288-192). In Integration processes in the modern professional education: Proceedings of the International Scientific and Practical Conference. Kazan: Publishing center MES RT.

Fakhrutdinova, A. V. (2011). Adaptation potential of foreign experience implementing civic education. Vocational education, 7, 69-71.

Fakhrutdinova, A. V. (2012). Changing the educational paradigm in the context of socio-economic transformation: Foreign experience (pp. 257-263). In Sustainable Socio-Economic Systems: Theory and Practice: Proceedings of the 1st International Scientific and Practical Conference. Kazan: Kazan University.

Gajazov, A. S. (1995). The Formation of the citizen: Theory, practice, problems. Chelyabinsk: Publishing house Celebration-TA "Torch".

Hollander, E. (2011). Civic education in research universities: leaders or followers? Education+Training, 53(2/3), 166-176.

Hutchinson, M. (2011). Outside the margins: Promotion and tenure with a public scholarship platform. Journal of Public Scholarship in Higher Education, 1, 133-151.

Jay, G. (2011). The engaged humanities: Principles and practices for public scholarship and teaching. Journal of Community Engagement and Scholarship, 3(1), 51-63.

Lesher, O. V. (1997). Intersocial education of student youth (theory and practice) (Doctoral dissertation). Chelyabinsk.

Rogova, G. V., Rabinovich, F. M., \& Sakharov, I. E. (1991). Methods of teaching foreign languages in secondary school. Moscow: Education.

Stanton, T. (2007). New times demand new scholarship: Opportunities and challenges for civic engagement at research universities. Education, Citizenship and Social Justice, 3(1), 19-42. http://dx.doi.org/10.1177/1746197907086716

Veremeeva, H. E. (1980). Students as a social group in the society. The structure of the students' consciousness. In Comprehensive approach to the students' communist up-bringing (pp. 38-54). Lvov: Vyschaya Shkola.

Yuzlikaeva, A. M. (1991). Moral education of students by means of a foreign language (Doctoral dissertation, Tashkent).

\section{Copyrights}

Copyright for this article is retained by the authors, with first publication rights granted to the journal. This is an open-access article distributed under the terms and conditions of the Creative Commons Attribution license (http://creativecommons.org/licenses/by/3.0/). 